\title{
FACTORS MOTIVATING PARTICIPATION IN PHYSICAL ACTIVITY IN STUDENTS OF WARSAW UNIVERISTY BY GENDER
}

\section{CZYNNIKI MOTYWUJĄCE DO PODEJMOWANIA AKTYWNOŚCI FIZYCZNEJ PRZEZ STUDENTÓW UNIWERSYTETU WARSZAWSKIEGO WEDŁUG PŁCI}

\author{
Magdalena Maria Fuhrmann ${ }^{1(\mathrm{~A}, \mathrm{~B}, \mathrm{C}, \mathrm{D}, \mathrm{E}, \mathrm{F}, \mathrm{G})}$
}

${ }^{1}$ Faculty of Geography and Regional Studies, University of Warsaw, Poland

Authors' contribution Wkład autorów: A. Study design/planning zaplanowanie badań B. Data collection/entry zebranie danych C. Data analysis/statistics dane - analiza i statystyki D. Data interpretation interpretacja danych E. Preparation of manuscript przygotowanie artykułu F. Literature analysis/search wyszukiwanie $i$ analiza literatury G. Funds collection zebranie funduszy
Tables: 3

Figures: 0

References: 29

Submitted: 2018 Apr 24

Accepted: 2018 Jun 07

\section{Summary}

Background. Physical activity is the primary factor in maintaining health and fitness. The minimal amount of physical activity per week is about 150 minutes of moderate activity. There are also many different motivation factors for activity, depending on various characteristics, for example, gender. The following article aims to prove how far gender can differentiate the motivation factor determining the amount of students' physical activity.

Material and methods. The study was carried out in 2016 in a group of 694 students of Warsaw University. The tool used to conduct the research was a proprietary questionnaire.

Results. The study showed that there are distinct differences between women and men. Firstly, the study allows for stating that students demonstrate different attitudes towards recreational activity. The second important outcome shows that intrinsic motivation is stronger in female students, while extrinsic factors play an essential role in males.

Conclusions. The obtained results on physical activity of students of Warsaw University remain partially in line with those found in other universities. Fitness improvement, weight reduction and well-being are the main motivation factors affecting the amount of physical activity. Another factor pointed out by students, and strongly emphasised by women, is taking care of own figure and physical condition. The element of pleasure concomitant with physical activity also becomes one of the most significant motivating factors for students of Warsaw University. Furthermore, male students are more likely to be driven by competition and selfexamination, while females are more into weight control.

Keywords: physical activity, gender, motivation

\section{Streszczenie}

Wprowadzenie. Aktywność fizyczna to jeden z czynników utrzymania zdrowia. Minimalny potrzebny poziom aktywności fizycznej to 150 minut umiarkowanej aktywności tygodniowo. Istnieje wiele czynników motywujących człowieka do podejmowania aktywności, a czynniki te zależą między innymi od płci. Niniejszy artykuł ma na celu ukazanie różnic w czynnikach motywujących do aktywności fizycznej wśród studentów i studentek Uniwersytetu Warszawskiego.

Materiał i metody. Badanie zostało przeprowadzone w 2016 roku wśród 694 studentów Uniwersytetu Warszawskiego. Wykorzystano autorski kwestionariusz ankiety.

Wyniki. Badanie pokazało, że istnieją pewne różnice pomiędzy aktywnością fizyczną kobiet i mężczyzn. Studenci posiadaja różne nastawienie do podejmowania aktywności fizycznej. Motywacja wewnętrzna (wrodzona) do podejmowania aktywności jest wyraźnie silniejsza wśród kobiet, u mężczyzn dominuje motywacja zewnętrzna.

Wnioski. Wyniki przeprowadzonych badań potwierdzają wiele z wyników osiagniętych w badaniach innych autorów. Rozwijanie sprawności fizycznej, reedukacja masy ciała oraz poprawa samopoczucia to najczęściej wymieniane czynniki motywujące do podejmowania aktywności fizycznej. Inne czynniki motywujące to - wskazane częściej przez kobiety potrzeba dbania o sylwetkę i kondycję fizyczną. Ważnym czynnikiem motywującym do podejmowania ruchu $\mathrm{w}$ czasie wolnym jest związana $\mathrm{z}$ aktywnością fizyczną przyjemność. Mężczyźni są częściej zmotywowani poprzez możliwość podejmowania rywalizacji i chęć sprawdzenia własnych możliwości, podczas gdy dla kobiet silniejszym motywatorem jest możliwość kontroli masy ciała.

Słowa kluczowe: aktywność fizyczna, płeć, motywacja 


\section{Introduction}

The primary purpose of physical activity is to improve physical and mental health [1], and the need for testing the activity is based on the willingness to improve physical activity plans [2,3]. Others point to some impact of physical activity on individual disease entities, from the group of heart, cardiovasular, bone or chronic diseases, as well as an impact on weight loss, an increase of energy and well-being $[4,5,6]$. The baseline of activity needed to achieve the above-mentioned effects is 150 minutes of moderate-intensity exercise per week. Physical activity is most crucial for young people, because of future health and social advantages [7].

It is a common object of interest in many studies on physical activity both in Poland and abroad $[8,9,10,11$, $12,13]$. The percentage of students participating in physical activity is very diverse, but still considered low. Another noticeable phenomenon is the decrease in physical activity after starting education [2, 14], as well as the age-conditioned decline in willingness to undertake physical activity $[15,16,17,18,19]$. The only exception shall be the case studies of Ashford, Biddle and Gouda [20], where mental health, socio-psychological or wellbeing motives were stronger in people over 45 years.

When it comes to physical activity management, it is essential to know the incentives to start that activity in the first place. Motivation means being "moved" to do something [21]. Kilpatrick, Hebert and Bartholomew highlight such characteristics as social belonging to the given group, appearance, competition, pleasure, health, agility, regeneration, recognition of the environment, strength and endurance, stress and weight management. According to Alvin Hung Chih Yu, motivational factors include health, appearance, social needs, self-education and pleasure. Teixeira, Carraca, Markland, Silva and Ryan [22] indicate that most young people have no motivation for physical activity or they have a low extrinsic motivation that does not lead to long-term activity.

One of the theories used to explain the motivation for taking physical activity is self-motivation theory (SDT) [23]. This theory forwards two different groups of incentives - intrinsic and extrinsic motivation. The first group includes satisfaction, joy, pleasure, personal achievements and excitement. The other group involves factors referred to as "instrumental reasons", which include, among others, a desire to avoid exclusion from the social group. The theory assumes that human beings demonstrate three basic psychological needs: a need for autonomy, competence and relatedness [14]. The extent of these needs is determined by the type of motivation. The types of motivation for meeting the abovementioned needs according to SDT are presented in Table 1.

Table 1. Motivation factors according to self-motivation theory (SDT)

\begin{tabular}{|c|c|c|c|c|}
\hline $\begin{array}{c}\text { Locus of inner } \\
\text { control }\end{array}$ & \multicolumn{4}{|c|}{ Locus of external control } \\
\hline True inner motivation & $\begin{array}{c}\text { Weak external } \\
\text { regulation }\end{array}$ & $\begin{array}{c}\text { Strong external } \\
\text { regulation }\end{array}$ & External regulation & Lack of motivation \\
\hline $\begin{array}{c}\text { "I exercise because it's } \\
\text { fun" }\end{array}$ & $\begin{array}{c}\text { "I exercise because I } \\
\text { want to look good" }\end{array}$ & $\begin{array}{c}\text { "I exercise because I } \\
\text { don't want to feel guilt } \\
\text { for leaving my team" }\end{array}$ & $\begin{array}{c}\text { "I exercise because my } \\
\text { parents want it" }\end{array}$ & $\begin{array}{c}\text { "I think exercising is a } \\
\text { waste of time" }\end{array}$ \\
\hline $\begin{array}{c}\text { Action to feel joy and } \\
\text { comfort, incentives are } \\
\text { not required }\end{array}$ & $\begin{array}{c}\text { Action is run by } \\
\text { internally defined } \\
\text { values }\end{array}$ & $\begin{array}{c}\text { Action is taken as an } \\
\text { internal need, but the } \\
\text { cause is an external } \\
\text { effects }\end{array}$ & $\begin{array}{c}\text { Action is ruled by } \\
\text { system of penalty and } \\
\text { incentive }\end{array}$ & $\begin{array}{c}\text { Action is not } \\
\text { happening because } \\
\text { there is no need to }\end{array}$ \\
\hline
\end{tabular}

Source: Kaupuzs A. The relationship between physical activity and exercise motivation of the first year students from Rezekne Augtskola. Lase Journal of Sport Science. 2013; 4(1): 3-15.

On the other hand, Ingledew and Markland [24] consider personality traits as the source of motivation determining participation in PA. This results in particular motives leading to undertaking physical activity. The latter are then translated into activity-related behaviours. They also highlight the one's ability to influence behaviour directly through personality traits. The result of those elements is the actual participation in physical activity.

\section{Material and methods}

The presented results were collected in a survey conducted among 694 students of Warsaw University in 2016. The tool used to carry out the research was a proprietary questionnaire. Students represented different fields and stages of the study. The majority of the respondents $(67.8 \%)$ were women. Nearly $65 \%$ of the students declared regular physical activity - 2-3 times a week (52.1\%). 
The study included 23 motivation factors for undertaking physical activity. They were divided into 7 groups of mental, aesthetic, health, personality, economic, social and spatial factors. Each factor was evaluated on a five-point scale: 'it definitely doesn't matter', 'it doesn't matter', 'it's hard to say', 'it matters', and 'it definitely matters'. In the compilation of motivation factors, two of the strongest responses were presented. For further analysis, two extreme (positive and negative) responses were cumulated, resulting in creating a three-step scale. Next, using the SPSS v. 24.0 package, a chi-square test was performed to examine the relationship between the respondents' gender (nominal variable) and the declared validity of the motivation factors (ordinal variable). The connection between the above variables was verified based on statistical significance and the cut-off level of 0.05 .

\section{Results}

The most critical motivation factor for undertaking physical activity by students was the need to take care of themselves. This option was chosen by $90.5 \%$ of the female respondents. Health considerations came second $(89.1 \%)$, and the desire to have a slim silhouette was a third option (84.9\%). Other factors were chosen less frequently - the general need to be active, motivated slightly more than $70 \%$ of the women, and the pleasure from taking physical activity was an important factor for $66.7 \%$ of the students, just like hygienic considerations (66.5\%). Among men, the most crucial incentive was pleasure, but it was chosen by less than $80 \%$ of the students. Health considerations came second (76.5\%), followed by the need for self-care (73.9\%). Similarly, as in the case of female students, the fourth most common answer was the need for activity (70.4\%). The other two factors were the desire to have a slim silhouette (7.1\%) and relaxation (65.4\%).

The study allowed for determining the differences in motivation for physical activity depending on gender. The main difference between the two groups of students was the attachment of women to physicality and appearance and, in the case of men, to character and personality issues. The factors with the most significant indication differences were identified, and the differences were statistically significant (11 factors). In the case of two factors, the differences followed a statistical tendency. The factor with the most significant difference, i.e. „overweight” - was chosen by $57.2 \%$ of women and $27.5 \%$ of men. The second place in women was the desire to have a slim figure, where the difference in indications was 17.8 percentage points. Other factors that were more noticeable among women include the need for self-care, health considerations, the availability of fitness clubs, multi-pass and the availability of green areas. Men focused more on competition (24.9 percentage points difference), ambition, character formation, pleasure, desire to impress others and the opportunity to spend time with friends. On the level of statistical tendency, the differences concerned pleasure and the possibility to spend time with the ones that students actually care about.

Table 2. Factors that motivate students to undertake physical activity (in \%)

\begin{tabular}{|c|c|c|c|c|c|c|c|c|}
\hline \multirow[b]{2}{*}{ Motivation factor } & \multicolumn{3}{|c|}{ Women } & \multicolumn{3}{|c|}{ Men } & \multirow{2}{*}{$\begin{array}{c}\text { Chi square } \\
\text { df }=2\end{array}$} & \multirow{2}{*}{$\begin{array}{l}\text { Statistical } \\
\text { significance }\end{array}$} \\
\hline & $\begin{array}{c}\text { Not } \\
\text { important }\end{array}$ & $\begin{array}{l}\text { Hard } \\
\text { to say }\end{array}$ & Important & $\begin{array}{c}\text { Not } \\
\text { important }\end{array}$ & $\begin{array}{l}\text { Hard } \\
\text { to say }\end{array}$ & Important & & \\
\hline Health considerations & 3.2 & 7.7 & 89.1 & 5.2 & 18.3 & 76.5 & 12.746 & 0.002 \\
\hline Hygiene considerations & 8.8 & 24.6 & 66.5 & 13.1 & 28.8 & 58.2 & 3.501 & 0.174 \\
\hline Need for activity & 12.0 & 16.9 & 71.1 & 11.8 & 17.8 & 70.4 & 0.052 & 0.975 \\
\hline Pleasure & 10.2 & 23.2 & 66.7 & 7.2 & 15.0 & 77.8 & 5.949 & $\underline{0.051}$ \\
\hline Relaxation & 16.5 & 24.9 & 58.6 & 11.8 & 22.9 & 65.4 & 2.416 & 0.299 \\
\hline Character shaping & 30.9 & 26.3 & 42.8 & 24.2 & 19.6 & 56.2 & 7.197 & 0.027 \\
\hline $\begin{array}{c}\text { Medical } \\
\text { recommendation }\end{array}$ & 78.9 & 10.6 & 10.6 & 78.4 & 9.8 & 11.8 & 0.189 & 0.910 \\
\hline Need for competition & 76.8 & 12.7 & 10.6 & 43.4 & 21.1 & 35.5 & 53.373 & $<0.0001$ \\
\hline Ambition & 33.0 & 28.1 & 38.9 & 19.0 & 24.8 & 56.2 & 13.958 & 0.001 \\
\hline $\begin{array}{c}\begin{array}{c}\text { Desire to impress } \\
\text { others }\end{array} \\
\end{array}$ & 67.6 & 16.9 & 15.5 & 49.0 & 24.8 & 26.1 & 14.671 & 0.001 \\
\hline Need for self-care & 3.2 & 6.3 & 90.5 & 8.5 & 17.6 & 73.9 & 21.357 & $<0.0001$ \\
\hline Overweight & 27.4 & 15.4 & 57.2 & 61.4 & 11.1 & 27.5 & 49.581 & 0.0001 \\
\hline Silhouette shaping & 4.6 & 10.6 & 84.9 & 19.7 & 13.2 & 67.1 & 27.619 & 0.0001 \\
\hline $\begin{array}{l}\text { Availability of fitness } \\
\text { club network }\end{array}$ & 55.4 & 21.1 & 23.5 & 68.4 & 19.7 & 11.8 & 9.807 & 0.007 \\
\hline
\end{tabular}




\begin{tabular}{|c|c|c|c|c|c|c|c|c|}
\hline $\begin{array}{c}\text { Availability of green } \\
\text { areas }\end{array}$ & 38.0 & 27.5 & 34.5 & 50.0 & 19.7 & 30.3 & 6.290 & $\mathbf{0 . 0 4 3}$ \\
\hline Outoor gyms & 69.1 & 19.3 & 11.6 & 71.2 & 17.0 & 11.8 & 0.353 & 0.838 \\
\hline Meeting with friends & 56.5 & 20.0 & 23.5 & 50.3 & 15.7 & 34.0 & 5.721 & $\underline{0.057}$ \\
\hline Meeting new people & 67.0 & 17.5 & 15.4 & 59.2 & 21.7 & 19.1 & 2.632 & 0.268 \\
\hline Fashion & 78.5 & 13.7 & 7.7 & 81.7 & 11.8 & 6.5 & 0.620 & 0.733 \\
\hline Multi-pass & 73.0 & 9.8 & 17.2 & 85.6 & 5.2 & 9.2 & 9.090 & $\mathbf{0 . 0 1 1}$ \\
\hline $\begin{array}{c}\text { Physically active } \\
\text { family }\end{array}$ & 76.5 & 11.2 & 12.3 & 72.5 & 17.6 & 9.8 & 3.786 & 0.151 \\
\hline $\begin{array}{c}\text { Physically active } \\
\text { friends }\end{array}$ & 51.9 & 24.9 & 23.2 & 51.6 & 25.5 & 22.9 & 0.018 & 0.991 \\
\hline $\begin{array}{c}\text { Need for leisure time } \\
\text { management }\end{array}$ & 30.6 & 32.7 & 36.6 & 26.8 & 31.4 & 41.8 & 1.260 & 0.533 \\
\hline
\end{tabular}

Source: Own work on the basis of own research

Table 3. Most significant indication differences in motivation factors for undertaking physical activity in students of Warsaw University

\begin{tabular}{|c|c|c|c|}
\hline \multicolumn{2}{|l|}{ Women } & \multicolumn{2}{|l|}{ Men } \\
\hline Factor & $\begin{array}{l}\text { Indication } \\
\text { difference }\end{array}$ & Factor & $\begin{array}{l}\text { Indication } \\
\text { difference }\end{array}$ \\
\hline Overweight & 29.7 & Need for competition & 24.9 \\
\hline Slim silhouette & 17.8 & Ambition & 17.3 \\
\hline Need for self-care & 16.6 & Character shaping & 13.4 \\
\hline Health considerations & 12.6 & Pleasure & 11.1 \\
\hline Availability of fitness clubs & 11.7 & Desire to impress others & 10.6 \\
\hline Multi-pass & 8.0 & \multirow{2}{*}{ Meeting friends } & \multirow{2}{*}{10.5} \\
\hline Availability of green areas & 4.2 & & \\
\hline
\end{tabular}

Source: Author's own research

\section{Discussion}

The study leads to the conclusion that motivating factors for women are more clearly related to physicality and appearance. Women pointed out overweight, the need for a slim figure or self-care more often than men. What is interesting is that female students are more likely encouraged to undertake physical activity due to the environment (fitness clubs or the availability of green areas) or their economic situation (having a multi-pass ${ }^{1}$ ). Male students tend to focus more on factors related to personality, character traits and perception by others. They point to the need for competition, ambition or ability to shape character through activity, and the desire to impress others. Only on the level of statistical tendency, they chose pleasure (statistical significance 0.051) or the possibility of meeting friends more often than female students (statistical significance 0.057).

The factors indicated by women such as health considerations and the need for self-care show that they are more likely to have intrinsic motivation. In the case of men, the external factors (perception by others, perception of themselves) were stronger. In addition, women were more likely to be motivated by circumstances not included in SDT.

The factors observed in male students are related to the development of assertiveness, their desire to achieve new goals and self-esteem [25]. Among women, health considerations are crucial as motivation factors for participation in physical activity. Health is a natural result of physical activity; that is why such motivation does not seem surprising. In all of these considerations, one thing is particularly interesting - it is the fact that women tend to be more aware of health aspect, whereas young people consider "health", as something they do not need to care about.

It is worth stressing that intrinsic motivation is stronger in female students, while the extrinsic factors play an essential role in male students. In addition, factors outside the SDT theory associated with recreational space and their economic condition seem more important to women.

Given the division of motivational factors into four groups proposed by Gavin, Keough, Abravanel, Moudrakovski, Mcbrearty [25], which outlined mental health, pleasure, and stress reduction factors, female

\footnotetext{
1 A special pass for the use of sports facilities (fitness clubs, etc.) most often at no extra charge throughout the country; it allows one to use various sports and leisure facilities with one contract and a pass, most often co-funded by the employer, so the cost of such pass is often much lower than the cost of a regular gym or pool pass.
} 
students are more often characterised by factors from the second group, while male students are more often associated with factors related to pleasure and mental strength. The observed differences may suggest that female students show greater concern for health issues and they are aware of such aspects. Furthermore, as women in general, they often pay attention to their appearance and, by taking up physical activity, they want to be in good shape to be noticed by others, as well as enhance their external attractiveness. In turn, men show greater attachment to such masculine traits as the need to compete or face more significant challenges. One can even say that for female students physical activity is nothing more than just a means to an end, whereas for male students it is an end in and of itself because by the very fact of being active they are accepted by the environment.

\section{Conclusions}

The obtained results on physical activity in Warsaw University students remain partially in line with those found in other universities. And so, Łuczak and Kroma [26] point out fitness improvement, weight reduction and well-being as main motivation factors. In Dębska's [27] study, the primary drive for physical activity is taking care of own figure and physical condition, a factor also pointed out by students (strongly emphasised by women). Siwiński and Tauber [28] pointed to the element of pleasure derived from physical activity, which has also become one of the most important motivating factors for students of Warsaw University. Kilpatrick, Hebert, Bartholomew [2] reported that men are more likely motivated by competition and self-examination, while women are more into weight control. Likewise, Asford, Biddle and Goudas [20] found out that male students were more motivated by endurance issues than females, and their research conclusions indicated the differences in motivation by gender. Finally, Baj-Korpak, Korpak, Szepeluk and Sudol [29] state that health is the prime factor determining physical activity.

\section{References:}

1. Centers for Disease Control and Prevention [Internet]. Atlanta: Centers for Disease Control and Prevention; 2011. Physical activity and health: the benefits of physical activity [cited 2017 Apr 20]. Available from: https://www.cdc.gov/physicalactivity/basics/pa-health/

2. Kilpatrick M, Hebert E, Bartholomew J. College students' motivation for physical activity: differentiating men's and women's motives for sport participation and exercise. Journal of American College Health. 2005; 54(2): 87-94.

3. Garbaciak W, Mynarski W, Czapla K, Rozpara M. Wydolność tlenowa studentów o zróżnicowanej aktywności fizycznej. In: Mynarski W., editor. Teoretyczne i empiryczne zagadnienia rekreacji i turystyki. Katowice: AWF; 2008. p. 306-321 (in Polish).

4. Hung Chih Yu A. Exploring motivation for leisure-based physical activity: a case study of college students. In: Burns R, Robinson K., editors. Proceedings of the 2006 Northeastern Recreation Research Symposium. Newtown Square: Department of Agriculture, Forest Service, Northern Research Station; 2006. p. 342-349.

5. Hagger MS. Advances in motivation in exercise and physical activity. In: Ryan MR., editor. The Oxford handbook of human motivation. New York: Oxford University Press; 2012.

6. Hawker CL. Physical activity and mental well-being in student nurses. Nurse Education Today. 2012; 32(3): 325-331.

7. Strong WB, Malina RM, Blimkie CJR, Daniels SR, Dishman RK, Gutin B, et. al. Evidence based physical activity for school-age youth. The Journal of Pediatrics. 2005; 146: 732-737.

8. Klarin M, Pororoković A, Sacic SS, Arnaudova V. Some characteristics of social interactions among adolescents in Croatia, Bosnia and Herzegovina and Macedonia. J Psychol Res Behav Manag. 2012; 5: 163-172.

9. Rothon C, Goodwin L. Family social support, community «social capital» and adolescents' mental health and educational outcomes: a longitudinal study in England. Soc Psychiatry Psychiatr Epidemiol. 2012; 47: $697-709$.

10. Novak D, Doubova SV, Kawachi I. Social capital and physical activity among Croatian high school students. Public Health. 2016; 135: 48-55. https://doi.org/10.1016/j.puhe.2016.02.002

11. Kijo P. Aktywność fizyczna wśród studentów kierunków pedagogicznych łódzkich uczelni publicznych i niepublicznych. In: Barabasz Z, Zadarko E., editors. Aktywność przez całe życie. Zdrowie i sprawność studentów pod kontrolą. Krosno: Państwowa Wyższa Szkoła Zawodowa w Krośnie; 2010. p. 157-180 (in Polish).

12. Biernat E. Aktywność fizyczna mieszkańców Warszawy na przykładzie wybranych grup zawodowych. Warszawa: Oficyna Wydawnicza SGH; 2011 (in Polish). 
13. Baj-Korpak J, Soroka A, Sudoł G. Poziom aktywności fizycznej studentów kierunku Wychowanie Fizyczne AWF w Krakowie. Roczniki Naukowe Wyższej Szkoły Wychowania Fizycznego i Turystyki w Białymstoku. 2014; 10: 9-15 (in Polish).

14. Kaupuzs A. The relationship between physical activity and exercise motivation of the first year students from Rezekne Augstskola. Lase Journal of Sport Science. 2013; 4 (1): 3-15.

15. Biddle SH. Exercise motivation across the life span. In: Smith D, Bar-Eli M., editors. Essential readings in sport and exercise psychology. Champaign, IL: Human Kinetics.; 2007. p. 378-389.

16. Brunet J, Sabiston CM. Exploring motivation for physical activity across the adult lifespan. Psychology of Sport and Exercise. 2011; 12(2): 99-105.

17. Ransford HE, Palisi BJ. Aerobic exercise, subjective health and psychological well-being within age and gender subgroups. Social Science and Medicine. 1996; 42(11): 1555-1559. https://doi.org/10.1016/0277-9536(95)00252-9

18. Seippel 0. The meanings of sport: fun, health, beauty or community? Sport in Society. 2006; 9(1): 51-70.

19. Trujillo KM, Brougham RR, Walsh DA. Age differences in reasons for exercising. Current Psychology. 2004; 22(4): 348-367. https://doi.org/10.1007/s12144-004-1040-z

20. Ashford BB, Biddle SS, Gouda MM. Participation in community sports centres: motives and predictors of enjoyment. Journal of Sports Science. 1993; 11(3): 249-256. https://doi.org/10.1080/02640419308729992

21. Ryan RM, Deci EL. Intrinsic and extrinsic motivations: classic definitions and new directions. Contemporary Educational Psychology. 2000; 25: 54-67.

22. Teixera PJ, Caracca EV, Markland D, Silva MN, Ryan RM. Exercise, physical activity, and self-determination theory: a systematic review. International Journal of Behavioral Nutrition and Physical Activity. 2012; 9: 78. https://doi.org/10.1186/1479-5868-9-78

23. Ryan RM, Williams GC, Patrick H, Deci EL. Self determination theory and physical activity: the dynamics of motivation in development and wellness. Hellenic Journal of Psychology. 2009; 6: 107-124.

24. Ingledew DK, Markland D. The role of motives in exercise participation. Psychology and Health. 2008; 23(7): 807-828.

25. Gavin J, Keough M, Abravanel M, Moudrakovski T, Mcbrearty M. Motivations for participation in physical activity across the lifespan. Intenational Journal of Wellbeing. 2014; 4(1): 46-61. https://doi.org/10.5502/ijw.v4i1.3

26. Łuczak J, Kroma M. Rekreacyjna aktywność fizyczna w stylu życia studentów Wyższej Szkoły Bankowej w Poznaniu. Studia Periegetica. 2015; 1(13): 123-143 (in Polish).

27. Dębska M. Stan aktywności fizycznej studentów. Polski Przegląd Nauk o Zdrowiu. 2014; 2(39): 138-142 (in Polish).

28. Siwiński W, Tauber RD. Rekreacja ruchowa.Zagadnienia teoretyczno-metodologiczne. Poznań: Wydawnictwo Naukowe Wyższej Szkoły Hotelarstwa i Gastronomii; 2004 (in Polish).

29. Baj-Korpak J, Korpak F, Szepeluk A, Sudoł G. Czynniki warunkujące motywy i bariery aktywności fizycznej studentów wychowania fizycznego. Rozprawy Społeczne. 2016; 10(4): 60-72 (in Polish). 